\title{
Nationalism in the Border Area: A Portrait of Sebatik Island
}

\author{
Adolfo Eko Setyantoํㅛ Ignatius Agung Satyawan², Sri Herwindya Baskara Wijaya², Salieg Luki \\ Munestri2 \\ ${ }^{`}$ Department of Communication, Universitas Sebelas Maret, Jalan Sutami 36A, Surakarta 57126, Indonesia \\ ${ }^{2}$ Center for ASEAN Studies, Universitas Sebelas Maret, Jalan Sutami 36A, Surakarta 57126, Indonesia \\ adolfoeko@staff.uns.ac.id,agungsatyawan@staff.uns.ac.id,r_windya@yahoo.com, salieglukim@gmail.com
}

\begin{abstract}
Keywords: Nationalism; Border area; Sebatik Island
Abstract: Nationalism is an important aspect in sustaining the existence of nation-state but on the other hand it can also be a cause of disintegration if the government neglect on caring a certain area including the border area. The border area often lacks allocation of resources of the development. Therefore, this area is often still backward and poor. This article analyzes nationalism in the Sebatik Island in the Province of North Kalimantan bordering Malaysia. Although its citizens live within limitations and their daily needs are supplied from Malaysia, they still have a high spirit of nationalism towards Indonesia.
\end{abstract}

\section{INTRODUCTION}

Nationalism has long been an interesting study among experts. On the one hand it is the foundation of the nation-state (hereafter state), but on the other hand it can be a source of conflict and fragmentation. Therefore, nationalism and the state have a mutually close relationship.

Nationalism exists and develops usually in a certain territory of a state. However, it is a question if the practice of nationalism is the same between the center and periphery territory. The general assumption shows that the border area is underdeveloped and poor. Because of its location away from the center of power, border area is often neglected by allocation of development outcomes. Therefore, nationalism among people living in the border area is lower than those who live in the center of power.

This article analyzes Indonesian nationalism in Sebatik Island, an island located in the outermost position and adjacent to the State of Sabah Malaysia. The discussion in this article includes first, elaboration of the concept of nationalism; second, the elements of the state to establish nationalism in the border area; third, the portrait of nationalism in Sebatik Island and the fourth is the conclusion.

\section{METHODS}

This article is carried-out using descriptive qualitative approach. Main data and information are collected through observation, library research and interviews with community leaders and government officials.

Data are validated by using the triangulation technique, especially sources' triangulation. Meanwhile, an interactive model was applied on data analysis and conclusion is drawn from collecting, reducing and displaying data (Miles and Huberman, 1994).

\section{RESULTS AND DISCUSSIONS}

\subsection{Explaining Nationalism}

Explaining Nationalism is not an easy job. It contains multi-interpretation of meanings and its different applications depending on the context and the interpreter. Nationalism can be interpreted as patriotism, loyalty to the nation, ideology, ethnicity, nation identity and so on (Calhoun, 1997; Haas, 1986). The most important thing in the spirit of nationalism is its ability to unite various people and their interests in one goal. So, nationalism is more 
concerned with consciousness and it is an imagination construction of the unity of community that well known as a nation (Anderson, 1983).

Nationalism had once been a powerful tool for colonized territories to establish an independent state. When the state has been established, it is the duty of the state to maintain nationalism. Long before the state of Indonesia existed, for example, the educated youth who was filled with the spirit of nationalism began to initiate to establish an independent Indonesian state, free from the Dutch colonialism. This idea became a reality on August 17,1945 . To maintain the existence of the state, the spirit of nationalism must be preserved.

In order to develop nationalism, especially in the borders area adjacent to other countries, there are several elements of the state that have to be taken into consideration. These elements are first, the state's vision of the periphery territory; second, the approach adopted to manage border area; third, the rules of the game used to deal with border area; and fourth, formal tools in managing border issues (Noor, 2016).

\subsection{Description of Sebatik Island}

Sebatik Island is Indonesia's outer islands bordering the state of Sabah, Malaysia. The island is divided into two, the northern part of Malaysia and the southern part of Indonesia with an area of 246.61 $\mathrm{km}^{2}$ and a population of about 40.645 people by 2015 (Siburian, 2015, Ghafur, 2016). The population of Sebatik Island Indonesia is much higher than that of Sebatik Malaysia which is designated as a plantation area.

Sebatik Island residents in general are migrants from various ethnic groups, especially from South

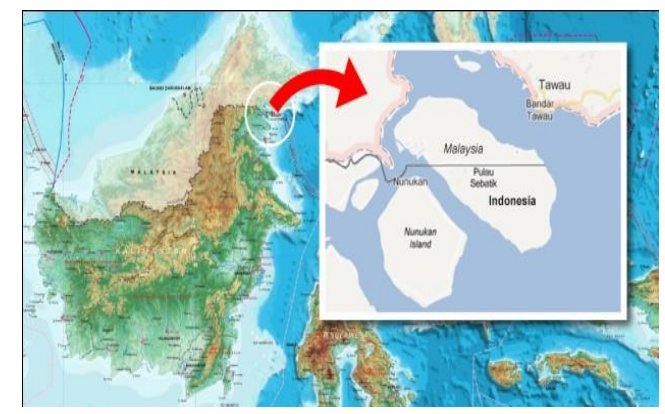

Figure 1: Map of Sebatik Island

Source: http://www.batasnegeri.com/pemerintah-akanbangun-bandara-di-pulau-sebatik/
Sulawesi, Java, East Nusa Tenggara and local indigenous ethnic Dayak Tidung. The Migrant resident of Sebatik Island originated from Indonesian laborers who deported by the Malaysian Government as relating to legality issues. They work in the farming plantation, especially oil palm and cocoa. In addition, a small part they became fishermen and traders.

Sebatik Island, which is administratively divided into five districts, is part of Nunukan Regency, North Kalimantan Province. The island has abundant resources but has not yet been fully exploited. The main potential of Sebatik is the agriculture sector such as palm, cocoa, and banana. In addition, in the marine sector, Sebatik waters are rich in various types of fish. The product of the agricultural sector and fish catch are mostly sold to Malaysia. Otherwise, Malaysian goods for daily needs are commonly found in Sebatik.

The level of welfare of Sebatik people and even of North Kalimantan is still minimal. Based on the Human Development Index (HDI), the welfare rate of North Kalimantan people is below the national average. In 2015, Indonesian HDI was 0.695 but HDI of North Kalimantan province was 0.687 (https://en.wikipedia.org/wiki/Daftar_provinsi_di_In donesia_menurut_IPM). It is very contrast If compare to HDI of Sabah Malaysia. The HDI of Sabah, though it was the lowest among states in $\begin{array}{lll}\text { Malaysia, it was } & 0.729\end{array}$ (https://www.skyscrapercity.com/showthread.php?t= 1367815). Based on this level of prosperity, the economic penetration of Malaysia is felt in Sebatik. In this Island, two currencies, Ringgit and Rupiah are used simultaneously for buying and selling. 


\subsection{The Development of Nationalism}

As mentioned earlier, the state has an obligation to develop the spirit of nationalism in its territory so that the existence of the country concerned can be sustainable. Successful development of nationalism depends on various factors. Firstly, is how the central government's vision of the border region. For decades the central government considers the border area to be the backyard of the country because it is remote and underdeveloped and a source of threat to the central government. Therefore, the appropriate approach to this vision is the security approach.

Different from now, Indonesia under the leadership of President Joko Widodo (Jokowi) has a vision that the border area is the front page of a country. Therefore, border area should not be left behind from other regions. In accordance with the Nawa Cita Program, Sanskrit words that means nine development priorities, President Jokowi takes priority for returning the state to its task of protecting all citizens and providing a safe environment, including in the border area. So, the preferred approach in border area development is prosperity and environmental approaches without neglecting security approach. With regard to the border area, Jokowi prioritizes infrastructure development, including trans-Kalimantan road parallel to the borderline with Malaysia and the sea toll. Through adequate infrastructure, local economic activities can be maximized.

Secondly, the next important aspect of dealing with border area, although has no directly related to the management of nationalism, is the legal aspect. The government's serious concern in developing border area can be seen at Law No. 43 of 2008 on State Territories. The law mentions that the territory of the state needs to be regulated for the integrity and sovereignty of the state in order for achieving prosperity for all people including who live in the border area. In addition, President Jokowi issued President Regulation number 2, 2015 on the Mid-term National Development Plan 2015-2019 mentioning that the border area as the front page of the state as a gate for economic and trade activities.

Thirdly, in relation to the formal aspects of the bureaucracy to manage border area issues intensively, in 2010 President published Presidential Regulation number 12 on the National Agency for Border Management. The main task of this Agency is to cultivate and develop values of nationalism as well as to socialize the spirit of defending for the country in the border are.

Through a change of vision and approaches, for several years there has been an increase in welfare. This can be seen from the increase of HDI figures of North Kalimantan Province from 2013 to 2016 of $0679 ; 0.686 ; 0.688$; and 0.692 respectively (http://ipm.bps.go.id/data/kabkot/metode/baru/6500 ) .

Although citizens of Sebatik Island live within the limits of both the social and economic facilities as consequences of the lack of infrastructure depend on Malaysia for daily needs, their nationalism is still high and loyal to the government. No separatist movement has emerged from the border area in North Kalimantan. A Javanese ethnic leader in Sebatik said that we Javanese people live in harmony with various ethnic here and feel of Sebatik as a miniature of Indonesia. Although our economy is supplied from Malaysia, we remain Indonesian (Interview, July 31 2017).

What was said by the Javanese community leader was indeed proven. A few weeks before the anniversary of the proclamation of 17 August in 2017, along the main road of Sebatik Island installed billboards and flags that symbolized the spirit of their nationalism. Even at the 2017 proclamation anniversary, Sebatik youth broke Indonesia's record with most participants of national flag-raising ceremonies.

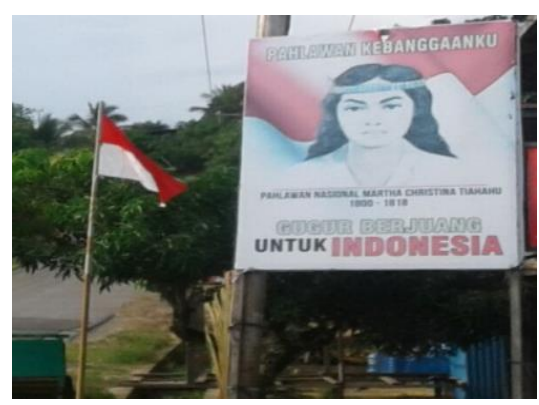

Figure 2: Billboard of National Hero on Main-road of Sebatik

Source: Personal documentation

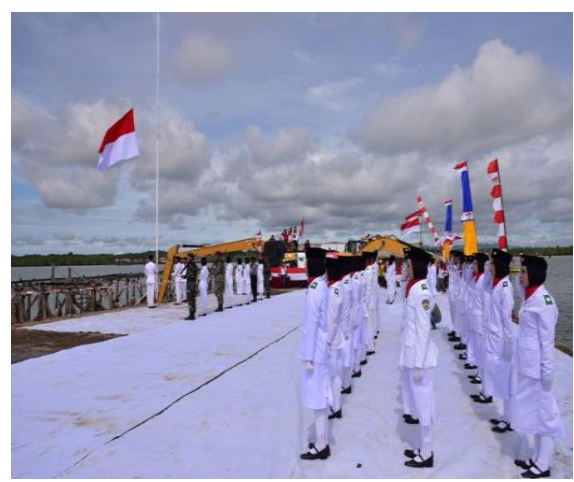

Figure 3: Raising National Flag Ceremony

Source:https://nasional.kompas.com/read/2017/08/18/07 130031/upacara-peringatan-kemerdekaan-ri-di-sebatikpecahkan-rekor-muri 


\section{CONCLUSIONS}

Nationalism has become a much-debated issue. On the one hand, nationalism can be a tool for building the state, but on the other hand, it can become a factor of disintegration, especially in the area of the country that the government is not paying attention to the border region.

Considering the importance of the border area, the Indonesian government under President Jokowi has changed the paradigm and approach in dealing with border area. He made the border into the front page of Indonesia while applying through prosperity approach. The result is an increase in HDI figures in the province of North Kalimantan Sebatik Island located on the border of Malaysia; its citizens still have nationalism and loyalty to Indonesia despite living within limitations. This can be seen when the commemoration of Indonesia's proclamation of 17 August. They celebrate with high enthusiasm.

\section{REFERENCES}

Anderson B. (1983). Imagine Communities: Reflection on the Origin and Spread of Nationalism, London: Verso.

Calhoun C. (1997). Nationalism. Minneapolis, University of Minneapolis Press, 1997

Ghafur, M. F. (2016). Ketahanan Sosial di Perbatasan: Studi Kasus Pulau Sebatik. Masyarakat Indonesia. 42 (2), 233-47. Available at http://jmi.ipsk.lipi.go.id/index.php/jmiipsk/article /download/669/502

Hass, E. B. (1986). What is Nationalism and Why Should We Study it? International Organization. 40 (3), 707-44

Miles, M. B., \& Huberman, M. (1994). Qualitative data analysis. ( $\left.2^{\text {nd }} \mathrm{ed}.\right)$. London: Sage.

Noor, F. (2016). Negara dan Kedaulatan Politik: Evaluasi Atas Pemeliharaan Rasa Kebangsaan oleh Negara. In Noveria, M. (ed.). Kedaulatan Indonesia di Wilayah Perbatasan: Perspektif Multidimensi. Jakarta; Yayasan Obor.

Siburian, R. (2012). Pulau Sebatik: Kawasan Perbatasan Indonesia Beraroma Malaysia. Masyarakat \& Budaya. 14 (1), 53-76. Available at http://jmb.lipi.go.id/index.php/jmb/article/viewFi le/87/68

http://ipm.bps.go.id/data/kabkot/metode/baru/6500

http://www.batasnegeri.com/pemerintah-akan-bangunbandara-di-pulau-sebatik/

https://id.wikipedia.org/wiki/Daftar_provinsi_di_Indones ia_menurut_IPM

https://nasional.kompas.com/read/2017/08/18/07130031/ upacara-peringatan-kemerdekaan-ri-di-sebatikpecahkan-rekor-muri https://www.skyscrapercity.com/showthread.php?t=1367 815 